\title{
CYTOTOXICITY EFFECT OF IONIC LIQUID- GRAVIOLA FRUIT (Annona muricata) EXTRACT TO HUMAN COLON CANCER (HT29) CELL LINES
}

\author{
DJabir Daddiouaissa ${ }^{1,2 *}$, AzUra Amid ${ }^{2}$, NASSEREldeen AhMEd KabBashi, \\ AHMED ADAM MOHAMMED ElNOUR ${ }^{1,2}$ AND MOHAMAD ADIKA KHAIRY BIN \\ MOHD SHAIFUDIN EPANDY ${ }^{3}$ \\ ${ }^{1}$ Biotechnology Engineering Department, Kulliyyah of Engineering, \\ ${ }^{2}$ International Institute for Halal Research and Training (INHART), \\ International Islamic University Malaysia, \\ Jalan Gombak, 53100 Kuala Lumpur, Malaysia \\ ${ }^{3}$ Adikafirdaus Resources, Lot 24, Jalan Klebang Selatan, 2/5 Kampung Tersusun, \\ Batu 6 Klebang Selatan, 31200 Ipoh, Perak, Malaysia \\ *Corresponding author: daddiouaissa.djabir@live.iium.edu.my
}

(Received: $3^{\text {rd }}$ November 2020; Accepted: $31^{\text {st }}$ March 2021; Published on-line: $4^{\text {th }}$ July 2021)

\begin{abstract}
The present study aimed to investigate the anti-proliferative effect of the ionic liquid-Graviola fruit (IL-GFE) extract on colon adenocarcinoma (HT29) cell lines and their kinetics behaviour to assess the Graviola fruit potential as a therapeutic alternative in cancer treatment. The phytoconstituents content of IL-GFE was identified using GC-TOFMS apparatus and measured its cytotoxicity on HT29 by tetrazolium bromide. Then the cytokinetic behaviour of the treated HT29 cells with IL-GFE was illustrated using the cells' growth curve. Besides, the cell cycle phase perturbation for the treated HT29 was applied using a flow cytometry technique. Qualitative identification of phytoconstituents of IL-GFE showed that Graviola fruit contains acetogenins, alkaloids, flavonoids, tannins and saponins compounds. IL-GF extract displayed a cytotoxicity effect on HT29 cells with the $\mathrm{IC}_{50}$ value of $10.56 \mu \mathrm{g} / \mathrm{mL}$, while Taxol showed an $\mathrm{IC}_{50}$ value of $1.22 \mu \mathrm{g} / \mathrm{mL}$. IL-GFE also decreased the cell generation number from 3.93 to 2.96 generations compared to Taxol-treated cells 2.01 generations. The microscope observation of the HT29 cells treated with the crude IL-GFE displayed loss of density and cell detachment. The extract's growth inhibition was related to the cell cycle arrest at the G0/G1 phase. IL-GFE inhibited colon adenocarcinoma HT29 cells' proliferation and affected their kinetic behaviour by lowering cell viability, inducing apoptosis, and arresting the cell cycle at the G0/G1 phase.
\end{abstract}

ABSTRAK: Kajian ini bertujuan untuk mengkaji kesan anti-proliferatif ekstrak buah-ion Graviola (IL-GFE) pada garis sel adenokarsinoma kolon (HT29) dan tingkah laku kinetik mereka untuk menilai potensi buah Graviola sebagai alternatif terapi untuk barah rawatan. Kandungan fitokonstituen IL-GFE dikenal pasti menggunakan alat GC-TOFMS dan mengukur sitotoksisitasnya pada HT29 oleh tetrazolium bromida. Kemudian tingkah laku sitokinetik sel HT29 yang dirawat dengan IL-GFE digambarkan menggunakan keluk pertumbuhan sel. Selain itu, gangguan fasa kitaran sel untuk HT29 yang dirawat diaplikasikan menggunakan teknik sitometri aliran. Pengenalpastian kualitatif fitokonstituen IL-GFE menunjukkan bahawa buah Graviola mengandungi asetogenin, alkaloid, flavonoid, tanin dan sebatian saponin. Ekstrak IL-GF memperlihatkan kesan sitotoksisiti pada sel HT29 dengan nilai IC $_{50} 10.56 \mu \mathrm{g} / \mathrm{mL}$, sementara Taxol menunjukkan nilai $\mathrm{IC}_{50} 1.22 \mu \mathrm{g} / \mathrm{mL}$. IL-GFE juga menurunkan jumlah penjanaan sel dari 3.93 hingga 2.96 generasi berbanding sel yang dirawat Taxol 2.01 generasi. Pemerhatian mikroskop 
sel HT29 yang dirawat dengan IL-GFE kasar menunjukkan kehilangan ketumpatan dan detasmen sel. Perencatan pertumbuhan ekstrak berkaitan dengan penangkapan kitaran sel pada fasa G0/G1. IL-GFE menghalang percambahan sel HT29 adenokarsinoma kolon dan mempengaruhi tingkah laku kinetik mereka dengan menurunkan daya maju sel, mendorong apoptosis, dan menghentikan kitaran sel pada fasa G0/G1.

KEYWORDS: colon cancer; cell cycle; flow cytometry; Graviola (Annona muricata); growth kinetics; GC-TOFMS; ionic liquids

\section{INTRODUCTION}

Fruit consumption is hugely recommended to preserve the healthy life of a human being. Annona muricata is known as Graviola, also called soursop in English, due to its sour and delicious fruit [1]. Graviola is predominately harvested in the tropical and subtropical regions of the world. Nowadays, Graviola fruit is vastly utilised to produce syrups, beverages and candies [2]. All Graviola tree parts have ethnobotanically reported being used in alternative medicine, mainly the fruit that is obtained to reduce worms and parasites [3], treat fever and enhance mother's milk [4], as well as renal, liver infections [5], hypertension [6] and cancer treatment [7]. The frequent use of Graviola in treating cancer may be related to its cytotoxic selectivity to cancer cells $[4,8,9]$. Also, studies have reported that the toxicity of Graviola to the cancer cells was more than healthy cells [10-12].

The potential anticancerous of the Graviola fruit extract was reported to be related to the phytochemicals called annonaceous acetogenins that are thought to be cytotoxic against different cancer cell lines, as highlighted in our previous study [13]. Recently, researchers are interested in the antitumor activity of acetogenins, as these are the main compounds isolated from the fruit [14]. The latest study confirmed that the IL-GFE showed selectivity toward cancer cells by affecting only the breast adenocarcinoma (MCF-7) cell lines but not the normal (VERO) cell lines, even with a high dose of $100 \mu \mathrm{g} / \mathrm{mL}$ [15]. This finding is in agreement with a study conducted by Dai et al. [11]. Hence, the Graviola fruit can be a promising substitute or complementary supplement to reduce tumour cell proliferation generally.

Colon adenocarcinoma is a frequently high incident rate in both sexes, with an estimation of 101,420 new cases and 51,020 colon cancer (CC) deaths in the United States in 2019 [16]. Therefore, it is hypothesised that the recent rapid declines in the colon cancer rate are due to the increased uptake of colonoscopy, which now is a useful screening test. Common used protocols in cancer treatment such as radiotherapy, chemotherapy and surgical intervention cause various side effects such as nausea, fatigue, hair loss, vomiting and weak immune system [17]. Hence, new approaches to treat cancer are highly recommended. Lately, our research team has successfully extracted bioactive compounds from Graviola fruit by ionic liquid-microwave-assisted extraction technique and showed a positive effect on breast cancer (MCF-7) cell line while it was safe toward normal VERO cell line [15]. Moreover, this extract did not cause any significant toxicity on the morphology of the treated zebrafish model [18].

Ionic liquid-based microwave-assisted extraction (IL-MAE) method has been applied successfully to the efficient extraction of bioactive compounds from medicinal plants. This is related to the high extraction efficiency, shorter extraction time and the unique properties of ILs which is proposed to be an environment-friendly technique in sample preparation. This may replace the well-known solvent used in extraction technique such as methanol $(\mathrm{MeOH})$ in which, its toxicity makes it undesirable for eco-friendly approaches [19]. It is expected that the IL-MAE method would be able to extract new bioactive compounds from 
Graviola fruit that are safe for human consumption to be used in cancer treatment. Many outcomes achieved by using ionic liquid-based processes in the extraction and isolation of several bioactive compounds such as small natural compounds from biomass, lipids, proteins, amino acids and pharmaceuticals [20].

Bogdanov [21] has reviewed the mechanism of ILs action in the process of solid-liquid extraction from the plant, showing that the ILs can attribute to the solvent-matrix interactions, which leads to the modification of permeability of the plant matrix. This is due to the disruption of the cell tissue and modifying the matrix permeability through the interaction of the $\mathrm{H}$ bonding with the carbohydrates from the cell walls. A previous study carried out by Cláudio et al. [22] reported that aqueous solution of $[\mathrm{C} 4 \mathrm{mim}] \mathrm{Cl}$ is the appropriate extractive solvent of caffeine from Paullinia cupana seeds (guaraná) in which, at the optimum extraction conditions of $\left(2.34 \mathrm{M}[\mathrm{C} 4 \mathrm{mim}] \mathrm{Cl}, 70{ }^{\circ} \mathrm{C}, 30 \mathrm{~min}, \mathrm{~s} / \mathrm{l}\right.$ ratio $\left.1: 10\right)$ the extraction efficiency was enhanced by $50 \%$ compared with the one obtained by Soxhlet extraction method using dichloromethane solvent. Another study conducted by Wang and co-workers. [23], reported that the 1-hexyl-3-methylimidazolium tetrafluoroborate [C6mim][BF4] water solution was used to extract lipophilic and hydrophilic metabolites from chrysanthemums and showed better extraction performance for the desired product than methanol. The ILs extraction ability relies on their physicochemical characteristics, such as hydrophobicity, hydrogen bonding ability and viscosity, which may have promising applications in the extraction of the natural product from plant supplies [24]. Thus, this research aimed to explore the phytochemical content and the potential anti-proliferative of the ionic liquid extract of Graviola fruit (IL-GFE) toward colon adenocarcinoma cell lines using MTT assay, cytokinetic behaviour and the flow cytometry technique.

\section{MATERIALS AND METHODS}

\subsection{Chemicals and Reagents}

All experimental chemicals utilised in this study were laboratory grade. The 1-Butyl-3Methylimidazolium Chloride [C4MIM][Cl] 96\% solution was obtained from (Alfa, USA). The N,O bis(trimethylsilyl)-trifluoroacetamide (BSTFA) 99\% was purchased from (SigmaAldrich, USA). Media for cell growth include Dulbecco's modified Eagle's medium (DMEM), fetal bovine serum (FBS) and penicillin/streptomycin were purchased from (GIBCO®, USA). For the anti-proliferative assay, the 3-(4,5-dimethylthiazol-2-yl)-2,5diphenyl-tetrazolium bromide (MTT reagent) and the accutase solution (cell detachment) were obtained from (ICT, USA). In addition, the RNase A / Prepodium iodide kit of the cell cycle assay was purchased from (Beckman Coulter, USA). All these reagents were utilised to evaluate the anti-proliferative activity of IL-GF extract on colon adenocarcinoma cell lines.

\subsection{Fruit Sample Preparation}

Graviola fruit samples (DB3) were chosen randomly from the farm of Adikafirdaus $\left(4.5921^{\circ} \mathrm{N}, 101.0901^{\circ} \mathrm{E}\right)$, Perak state, Malaysia. After that, the fruits were properly cleaned to eliminate all traces of insects and dust, removed the pericarp and seeds. The fruit pulp was then frozen at $-20{ }^{\circ} \mathrm{C}$ for $72 \mathrm{hrs}$, then freeze-dried using a lyophiliser (Christ Alpha) based on the methodology of Hoeing [25]. Next, the dried sample was weighed and stored in falcon tubes at $-20{ }^{\circ} \mathrm{C}$ for further analysis [26]. The fruit samples were stored in the herbarium with voucher number KAED/HBL/S1A047/2018/707 at the Kulliyyah of Architecture and Environmental Design, IIUM. The plant name was checked on www.theplantlist.org. 


\subsection{Fruit Sample Extraction}

The dried Graviola fruit sample was extracted as described in our previous study [15]. In brief, the dried sample was mixed at a ratio of $[1: 30] \mathrm{g} / \mathrm{mL}$ of $0.5 \mathrm{~mol} / \mathrm{L}$ of $[\mathrm{C} 4 \mathrm{MIM}][\mathrm{Cl}]$ reagent. The extract suspension was heated under a microwave oven with irradiation power of $700 \mathrm{~W}$ for $3 \mathrm{~min}$. Then, the fruit extract (IL-GFE) was cooled down to room temperature and then filtered using a $3 \mathrm{~mm}$ Whatman filter paper. A back extraction to recover the ionic liquid was applied using phase separation with ethyl acetate at a ratio of 1:2 [27]. The extract was then lyophilised by freeze drier for $72 \mathrm{hrs}$. Finally, the dried extract was stored at $4{ }^{\circ} \mathrm{C}$ chiller until further analysis [28,29].

\subsection{GC-TOFMS Sample Preparation and Analysis}

The phytochemicals content of IL-GFE was identified using gas chromatography (GCTOFMS) analysis; the dry IL-GF extract was silylated by using N,O bis(trimethylsilyl)trifluoroacetamide (BSTFA) / acetonitrile $(40: 60 ; 1000 \mu \mathrm{L})$ and incubated at $60{ }^{\circ} \mathrm{C}$ for one hour. The sealed vials were vortexed at an interval of $1 \mathrm{~min}$ to achieve complete silylation. Silyl derivatisation is a common process to raise the volatility and detectability of the chemical compound in GCMS analysis [30]. In this research, GC-TOFMS analysis of the IL-GFE used a 7890A Agilent-Technologies GC system formed by a 7693-mass spectrometer system detector (Agilent Technologies, USA). The method of Muhamad et al. [31] was adopted with modification. The MS detector was run with an electron energy of $70 \mathrm{eV}$ and a mass range of $\mathrm{m} / \mathrm{z} 50-550$. An HP-5 MS capillary column of $(30 \mathrm{~m} \times 0.25 \mathrm{~mm}$, $0.25 \mu \mathrm{m}$ film thickness) was utilised for separation. The GC oven temperature was set at 80 ${ }^{\circ} \mathrm{C}$ for $2 \mathrm{~min}$, then raised to $240{ }^{\circ} \mathrm{C}$ at $5{ }^{\circ} \mathrm{C} / \mathrm{min}$ and held for $5 \mathrm{~min}$ then finally increased to $300{ }^{\circ} \mathrm{C}$ at a rate of $3{ }^{\circ} \mathrm{C} / \mathrm{min}$ and kept for $5 \mathrm{~min}$. The temperature of the GC injector and MS transfer line was set at $225{ }^{\circ} \mathrm{C}$ and $300{ }^{\circ} \mathrm{C}$, respectively. The sample was injected in the splitless mode at a ratio of 1:10. The carrier gas (helium) was utilised at a constant flow rate of $1.2 \mathrm{~mL} / \mathrm{min}$. Consequently, essential compounds were identified by comparing their retention time and mass spectra with those of the standard and authentic compounds at the National Institute of Standard (NIST) library.

\subsection{Cell Culture}

In This Study, the colon adenocarcinoma HT29 cell line (ATCC No: HTB-22 ${ }^{\mathrm{TM}}$ ) was used as the experimental tumour cell. These cells were obtained from the American Type Collection Culture and stored in liquid nitrogen until further utilisation. After thawing the frozen cells, they were inoculated into $25 \mathrm{~cm}^{2}$ T-flask with $5 \mathrm{~mL}$ of complete media, including DMEM complemented with $10 \%$ FBS and $1 \%$ pen/strip. Next, the culture cells were incubated at a $95 \%$ humidified incubator with $5 \% \mathrm{CO}_{2}$ at $37{ }^{\circ} \mathrm{C}$. Then, the cells were used for further experimental analysis when they reached approximately $80 \%$ confluence.

\subsection{The MTT Cell Viability Assay}

The viable cell number was quantified using the tetrazolium-based colourimetric (MTT assay). The confluent cells were detached from the bottom of the T-flask by adding $2 \mathrm{~mL}$ of accutase, and then the cell was counted using a haemocytometer. Almost $5.0 \times 10^{4}$ cells were suspended in $100 \mu \mathrm{L}$ of media and plated in each well of 96-well plate then incubated in a $5 \% \mathrm{CO}_{2}$ incubator for $24 \mathrm{hrs}$. After removing the media, $20 \mu \mathrm{L}$ of serial dilutions $(6.25-$ $400 \mu \mathrm{g} / \mathrm{mL}$ ) of the IL-GF extract in media free-FBS were added to the cells (triplicate wells per condition). The negative control received only DMSO, and the positive control treated with Taxol $(0.39-6.25 \mu \mathrm{g} / \mathrm{mL})$. The treated cells were incubated for $48 \mathrm{hrs}$, then added 20 $\mu \mathrm{L}$ of MTT reagent $(5 \mathrm{mg} / \mathrm{mL})$ into different wells. The incubation was then extended for another 3 hours then the media was carefully discarded. Next, the solubilisation liquid 
(DMSO) $(100 \mu \mathrm{L})$ was applied to each well to solubilise formazan then shake for $15 \mathrm{~min}$ at room temperature [32]. Finally, the formazan absorbance was measured at $570 \mathrm{~nm}$ by a microplate reader. The percentage of viable/dead cells were calculated, and the $\mathrm{IC}_{50}$ of ILGF extract toward HT29 was determined using equation 1:

$$
\begin{aligned}
& \text { Percentage Cell Viability (\%) } \\
& \qquad=\frac{\text { Abs of treated cells }}{\text { Abs of untreated cells }} \times 100
\end{aligned}
$$

\subsection{The 50\% Inhibitory Concentration Estimation}

The inhibitory effect of the IL-GF extract on the colon cancer cell growth was shown as the inhibitory concentration that induced 50\% inhibition of the cell population (IC50). This $\mathrm{IC}_{50}$ value was obtained graphically by plotting the percentage of viable cells against the associated different concentrations of the IL-GF extract used. Findings were presented as the mean \pm one standard error (SE), and statistically, the $\mathrm{P} \leq 0.05$ level was considered acceptable.

\subsection{Growth Kinetics Study}

The growth kinetics study was performed to establish a model that predicted the ILGFE effect on treated and non-treated colon adenocarcinoma HT29 cell lines and compared it to Taxol-treated cells as a positive control. First, HT29 cells were counted and inoculated into $25 \mathrm{~cm}^{2}$ T-flask at $2.0 \times 10^{5}$ cells $/ \mathrm{mL}$ and incubated for $24 \mathrm{hrs}$. There were three groups of flasks in this study (triplicate flasks per condition): untreated HT29, Taxol-treated HT29 at the $\mathrm{IC}_{50}$ value of $1.22 \mu \mathrm{g} / \mathrm{mL}$ and HT29 treated with IL-GF extract at the $\mathrm{IC}_{50}$ value of $10.56 \mu \mathrm{g} / \mathrm{mL}$ [33]. The treated cells in 20 flasks per group were counted every $8 \mathrm{hrs}$ interval (from 0 to $144 \mathrm{hrs}$ ). After incubation, the media was discarded, and the cells received fresh media containing the samples, then incubated from 0 to $144 \mathrm{hrs}$. Cell images were observed and recorded every 8 hours using a 10X magnification microscope. After that, cells were harvested from a monolayer and quantified using a trypan blue dye exclusion assay [34]. Finally, the cell viability number was determined by using Eq. 2:

$$
C=n \times 2 \times 10^{4}
$$

Where $n$ presents the average of the quantified cells, the number $10^{4}$ is the conversion of volume $0.1 \mathrm{~mm}^{3}$ to 1 millilitre, and 2 is the dilution factor. The growth kinetics graph was plotted using the resulted data to calculate the number of cell generation, the specific growth rate and doubling time by using Eqs. (3), (4) and (5).

$$
\begin{gathered}
X=\frac{\log _{10} N-\log _{10} N_{0}}{\log _{10} 2} \\
\log _{10} N=\log _{10} N_{0}+\mu t \\
t_{d}=\frac{\log _{10^{2}}}{\mu}=\frac{0.301}{\mu}
\end{gathered}
$$

Where $(X)$ is the number of cell generation; $(N)$ is the number of cells at the end; $\left(N_{0}\right)$ is the primary number of cells; $(\mu)$ is the specific growth rate; $(\mathrm{t})$ is the duration of treatment; $\left(t_{d}\right)$ is the doubling time.

\subsection{Cell Cycle Assay}

The cell cycle phase perturbation in IL-GF extract-treated HT29 was analysed in a timedependent manner using flow cytometry. First of all, approximately $5.0 \times 10^{4}$ of colon HT29 cell lines were inoculated into $25 \mathrm{~cm}^{2}$ T-flask and incubated for $24 \mathrm{hrs}$. After that, the media 
was discarded and replaced with new media contains IL-GF extract at the $\mathrm{IC}_{50}$ concentration value, then incubated progressively for 24, 48 and $72 \mathrm{hrs}$. After harvesting the cells with accutase, cells were thoroughly washed using $1 \mathrm{X}$ PBS and centrifuged at $1500 \mathrm{rpm}$ for 5 $\min$. The cells were fixed for one hour with $2 \mathrm{~mL}$ of $70 \%$ ethanol then centrifuged at 4000 rpm for $10 \mathrm{~min}$ at room temperature. Then removed the supernatant and washed the cells with PBS. Next, the treated cells were stained with $500 \mu \mathrm{L}$ of $0.05 \mathrm{mg} / \mathrm{mL}$ of RNase A and $0.05 \mathrm{mg} / \mathrm{mL}$ of propidium iodide reagent in PBS [35]. The perturbation in cell cycle phases between the treated and untreated HT29 cells (10,000 events/group) was determined by the flow cytometry (CytoFLEX S, Beckman Coulter, USA). The cells in phases S and G2M were considered as proliferative cells and in the sub-G1 phase as apoptotic cells [36].

\subsection{Statistical Analysis}

The experiments of cell viability and cytokinetic growth were performed in triplicates, and the findings were displayed by the overall mean of three independent experiments \pm standard deviation (SD). The statistical analysis of the data was carried out using GraphPad Prism software (Version 7.00). One-way (ANOVA) analysis of variance and Tukey's test were applied using Minitab software (version 17; PA, USA) to show the significant differences. The statistical analysis was considered acceptable when $\mathrm{p} \leq 0.05$.

\section{RESULTS}

\subsection{GC-TOFMS Analysis}

The phytochemical content of the IL-GF extract was identified by using the GCTOFMS instrument. The secondary metabolites detected in the extracts were validated by measuring the similarity of the pattern obtained from the GC-TOFMS reader with the existing database pattern. Graviola fruit extract (GFE) constituents generally belong to the class of alkaloids, flavonoids, phenols, and acetogenins. According to many kinds of literature, these compounds have antidiabetic, anti-oxidant and anti-cancer activities [37]. The result of the GC-TOFMS analysis of IL-GF extract was shown in Table 1, where 55 compounds were identified as having greater than $70 \%$ similarity with the standard mass spectroscopy in the NIST library. The major components identified by GC-TOFMS were D-psicofuranose, pentakis ether $(13.53 \%)$, propyldecyl cyclopropane carboxylate $(7.86 \%)$, tri-ruthenium dodecacarbonyl (7.86\%), N-acetylimino dimethylsulfurane $(7.86 \%)$, mannopyranose $(7.74 \%)$, pyranone $(7.74 \%)$, carbohydrazide $(5.97 \%)$, nickel tetracarbonyl (5.57\%), benzoic acid (5.46\%), formic acid, ethenyl ester $(4.45 \%)$ and propanetriol, 1 acetate $(3.68 \%)$. Table 1 presents the complete list of bioactive components from the IL-GF extract.

\subsection{The IC I0 $_{50}$ of IL-GF Extract Against HT29 Cell Lines}

After plotting the graph of viable cells $(\%)$ vs different doses of the sample $(\mu \mathrm{g} / \mathrm{mL})$, The estimation of the IC 50 values for IL-GF extract and Taxol were $10.56 \mu \mathrm{g} / \mathrm{mL}$ (Fig. 1) and $1.22 \mu \mathrm{g} / \mathrm{mL}$ (Fig. 2), respectively. These findings confirmed that the IL-GF extract has significantly inhibited the HT29 cell proliferation in a dose-dependent manner. 
Table 1: Compounds present in the ionic liquid extract of Graviola fruit identified by GC-TOFMS

\begin{tabular}{|c|c|c|c|c|}
\hline $\begin{array}{l}\text { Peak } \\
\text { No }\end{array}$ & $\begin{array}{c}\text { Area } \\
\%\end{array}$ & Compound Name & R. time (s) & $\begin{array}{c}\text { Molecular } \\
\text { Weight g/mol }\end{array}$ \\
\hline 1 & 0.17 & 1-Chloropropylene & 180.232 & 76.01 \\
\hline 3 & 0.15 & Butanedione, monooxime & 182.125 & 101.05 \\
\hline 4 & 0.55 & Nitrous acid, methyl ester & 182.457 & 61.02 \\
\hline 2 & 0.44 & Alpha-Carotene & 194.044 & 536.44 \\
\hline 5 & 0.53 & Molybdenum carbonyl & 205.697 & 662.12 \\
\hline 6 & 0.80 & Propanediol, trimethylsilyl ether & 206.062 & 148.09 \\
\hline 7 & 1.70 & Pentanedione, 3-diazo & 206.626 & 126.04 \\
\hline 8 & 1.18 & Cyclopentane, 1-acetyl-1,2-epoxy & 206.925 & 126.07 \\
\hline 9 & 0.18 & Acetophenone, 4'-nitro-, thiosemicarbazone & 208.585 & 238.05 \\
\hline 10 & 0.69 & Propenoic acid, oxiranylmethyl ester & 213.964 & 128.05 \\
\hline 11 & 0.20 & Mercaptamine & 220.039 & 77.03 \\
\hline 12 & 0.13 & Nitroso-3-pyrroline & 232.921 & 98.05 \\
\hline 13 & 0.16 & Oxalic acid & 256.061 & 90.00 \\
\hline 14 & 0.92 & Acetic acid, (aminocarbonyl) & 264.295 & 132.02 \\
\hline 15 & 0.17 & Acronize & 270.105 & 478.11 \\
\hline 16 & 5.97 & Carbohydrazide & 275.251 & 90.05 \\
\hline 17 & 6.05 & Pyranone & 275.45 & 144.04 \\
\hline 18 & 4.45 & Formic acid, ethenyl ester & 276.014 & 72.02 \\
\hline 19 & 1.69 & Trifluoromethanesulfonic acid ethyl ester & 276.313 & 177.99 \\
\hline 20 & 0.44 & Ala-gly, trimethylsilyl ester & 289.593 & 218.11 \\
\hline 21 & 1.04 & Furanone, dihydro-4-hydroxy & 290.755 & 102.03 \\
\hline 22 & 0.18 & $\beta$-Phorbol & 296.565 & 686.48 \\
\hline 23 & 0.75 & Cyclobutane & 344.44 & 56.06 \\
\hline 24 & 0.15 & Butanoic acid, methyl ester & 344.672 & 185.03 \\
\hline 25 & 0.58 & Aminourea & 345.9 & 75.04 \\
\hline 26 & 0.23 & Cobalt, tetracarbonylsilyl & 357.321 & 201.91 \\
\hline 27 & 0.40 & Valeric acid hydrazide & 363.994 & 116.10 \\
\hline 28 & 0.19 & Oxotetrahydrofuran-2-carboxylic acid & 365.256 & 130.03 \\
\hline 29 & 0.30 & à-D-Glucopyranoside & 390.853 & 331.16 \\
\hline 30 & 3.68 & Propanetriol, 1-acetate & 397.46 & 134.06 \\
\hline 31 & 0.21 & n-Propyl fluoride & 443.741 & 62.05 \\
\hline 32 & 5.57 & Nickel tetracarbonyl & 451.41 & 169.92 \\
\hline 33 & 0.14 & L-Proline & 456.755 & 187.31 \\
\hline 34 & 7.86 & Propyldecyl cyclopropane carboxylate & 493.375 & 268.24 \\
\hline 35 & 7.86 & Tri-ruthenium dodecacarbonyl & 494.172 & 641.65 \\
\hline 36 & 7.86 & N-Acetylimino dimethylsulfurane & 494.271 & 119.04 \\
\hline 37 & 0.18 & Carbamic acid, ethylnitroso, ethyl ester & 537.564 & 146.07 \\
\hline 38 & 0.28 & Nitroethane & 573.486 & 75.03 \\
\hline 39 & 0.20 & Iron, hexacarbonyl & 704.128 & 762.16 \\
\hline 40 & 0.21 & Apigenin 8-C-glucoside & 706.386 & 432.11 \\
\hline 41 & 0.96 & Manganese, acetylpentacarbony & 769.632 & 237.93 \\
\hline 42 & 0.23 & Cyclobutanone & 939.317 & 70.04 \\
\hline 43 & 0.91 & Butanedioic acid & 945.625 & 350.63 \\
\hline 44 & 0.13 & Diethylene glycol, monotrimethylsilyl ether & 996.853 & 178.10 \\
\hline 45 & 0.20 & Trimethylene oxide & 1012.82 & 58.04 \\
\hline 46 & 0.53 & Silanol trimethyl, propanoate & 1098.31 & 146.07 \\
\hline 47 & 0.12 & Nitrohexane & 1105.82 & 131.09 \\
\hline 48 & 0.22 & $\beta$-Xylopyranose, tetrakis-TMS & 1334.63 & 438.21 \\
\hline 49 & 13.54 & D-Psicofuranose, pentakis ether & 1396.25 & 541.06 \\
\hline 50 & 7.74 & Mannopyranose & 1397.34 & 452.88 \\
\hline 51 & 1.10 & Erythro-pentonic acid & 1435.26 & 438.85 \\
\hline 52 & 0.22 & Gluconic acid, ç-lactone & 1435.46 & 421.71 \\
\hline 53 & 0.11 & Quinazolin-2(3H)-thione & 1974 & 392.16 \\
\hline 54 & 0.19 & Difluoroacetylene & 2278.77 & 62.00 \\
\hline 55 & 0.74 & Aucubin, hexakis & 2353.17 & 779.42 \\
\hline
\end{tabular}




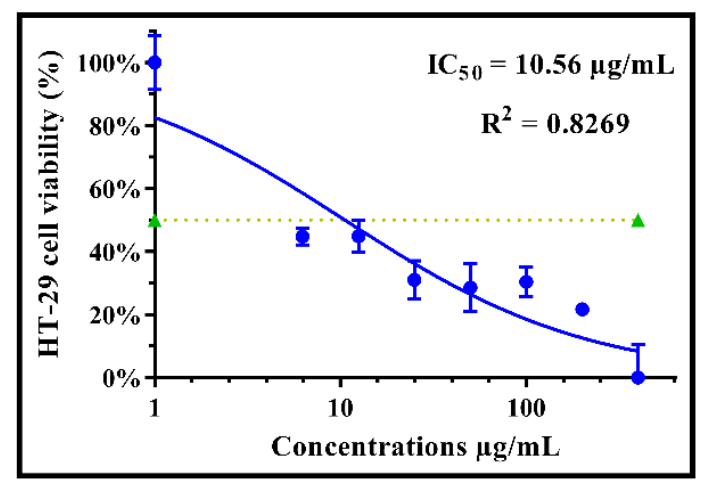

Fig. 1: The percentage of cell viability of colon adenocarcinoma HT29 cells vs different concentrations of IL-GF extract.

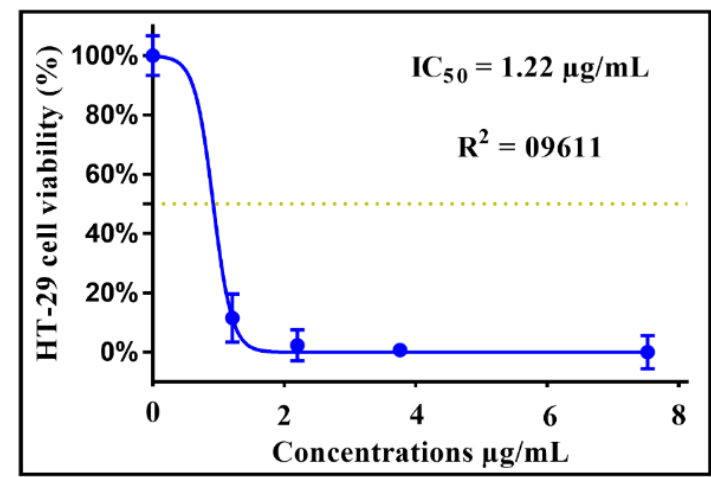

Fig. 2: The percentage of cell viability of colon adenocarcinoma HT29 cells vs different concentrations of Taxol.

\subsection{Effect of IL-GF Extract on HT29 Cell Growth Kinetics}

The growth kinetics graph of untreated HT29 cells (control), the IL-GF extract-treated HT29 $(10.56 \mu \mathrm{g} / \mathrm{mL})$ and Taxol-treated HT29 $(1.22 \mu \mathrm{g} / \mathrm{mL})$ were plotted and compared. The changes in the growth behaviour of the treated HT29 can be seen in (Fig. 3). First, in the lag phase, the untreated and treated HT29 cells' growth was similar until $16 \mathrm{hrs}$ of treatment. After that, a clear log phase was seen when the cells started to proliferate at 24 hrs. The IL-GF extract-treated HT29 cells took $72 \mathrm{hrs}$ to reach the peak, while the Taxol treated HT29 cells showed less exponential phase and a smaller number of cells than control cells.

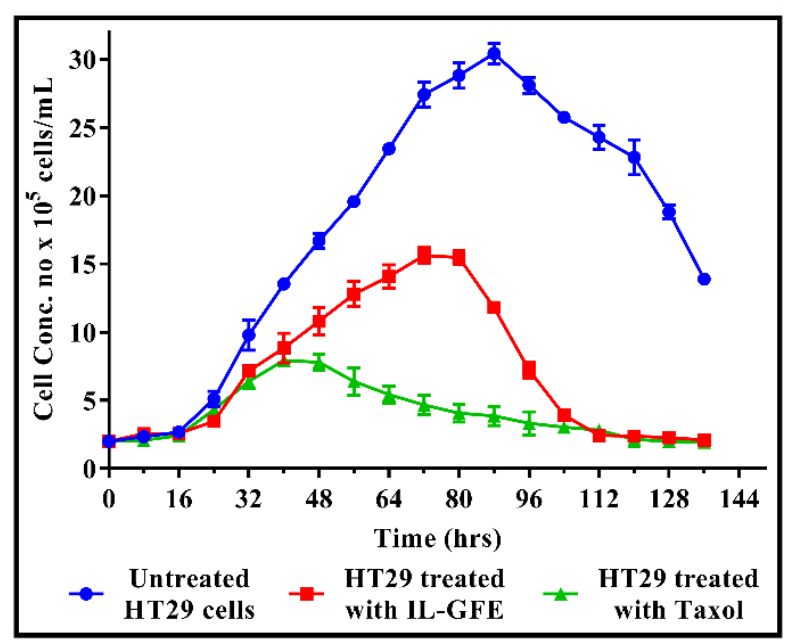

Fig. 3: Growth profiles of untreated HT29 cells and the treated with IL-GF extract $\left(\mathrm{IC}_{50}=10.56 \mu \mathrm{g} / \mathrm{mL}\right)$ and Taxol $\left(\mathrm{IC}_{50}=1.22 \mu \mathrm{g} / \mathrm{mL}\right)$.

From the growth curve, it can be seen that the untreated HT29 showed significant proliferation compared to the treated cells with IL-GF extract and Taxol. The cell number at the peak of the stationary phase for the treated HT29 cells with IL-GF extract and Taxol were only $15.6 \times 10^{5} \pm 0.592$ and $7.93 \times 10^{5} \pm 0.411$ cells $/ \mathrm{mL}$, respectively while the number reached $30.4 \times 10^{5} \pm 0.753$ for the control. Based on the growth curve (Fig. 3) and the fourth equation, cell growth at the log phase (Fig. 4A), the death phase (Fig. 4B), and the number of cell generations (Table 2) were obtained for all treatments. 
Table 2: The number of cell generations $(\mathrm{X})$, specific growth rate $(\mu)$ and duplication period (td) for HT29 control cells and the treated cells with IL-GF extract and Taxol

\begin{tabular}{ccccc}
\hline Cell growth & $\begin{array}{c}\text { Maximum cells } \\
\text { volume }(\mathbf{N}) \\
(\mathbf{c e l l s} / \mathbf{m L})\end{array}$ & $\begin{array}{c}\text { Number of } \\
\text { generations } \\
(\mathbf{X})\end{array}$ & $\begin{array}{c}\text { Specific growth } \\
\text { rate } \\
\boldsymbol{\mu}\left(\mathbf{h}^{-\mathbf{1}}\right)\end{array}$ & $\begin{array}{c}\text { Doubling } \\
\text { time } \\
\mathbf{t}_{\mathbf{d}}(\mathbf{h})\end{array}$ \\
\hline $\begin{array}{c}\text { Untreated HT29 cells } \\
\mathrm{IL}-\mathrm{GFE} \text { treated } \mathrm{HT} 29 \text { cells } \\
\left(\mathrm{IC} \mathrm{C}_{50}=10.56 \mu \mathrm{g} / \mathrm{mL}\right)\end{array}$ & $15.6 \times 10^{5} \pm 0.753^{\mathrm{a}} \pm 0.592^{\mathrm{b}}$ & 3.93 & 0.0134 & 22.46 \\
$\begin{array}{c}\text { Taxol treated } \mathrm{HT} 29 \mathrm{cells} \\
\left(\mathrm{IC}_{50}=1.22 \mu \mathrm{g} / \mathrm{mL}\right)\end{array}$ & $7.93 \times 10^{5} \pm 0.411^{\mathrm{c}}$ & 2.01 & 0.0124 & 24.27 \\
\hline
\end{tabular}

*For all experiments, the initial number of cells (N0) was fixed at $2.0 \times 10^{5}$ cells $/ \mathrm{mL}$. Different superscripts (a, b, c) display a significant difference $(\mathrm{p} \leq 0.05)$.
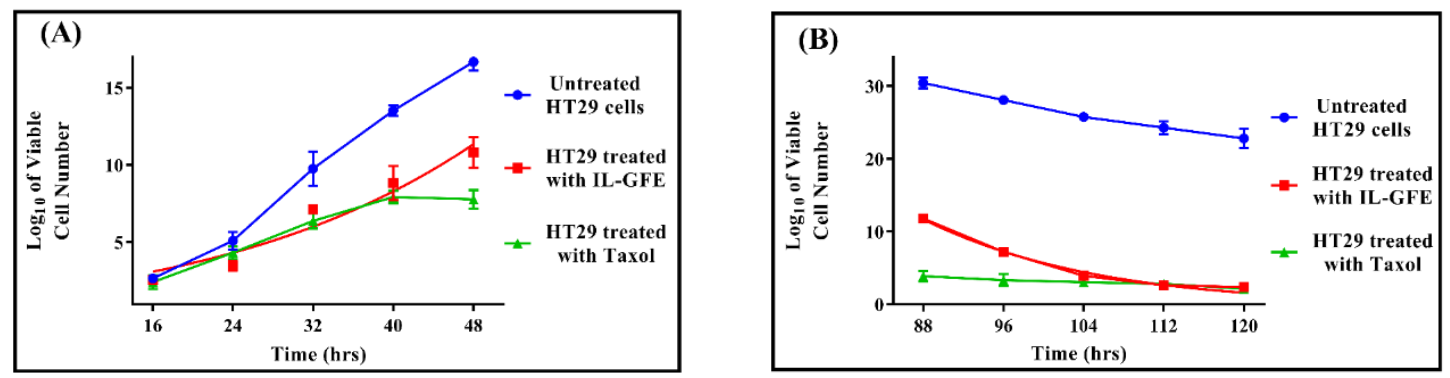

Fig. 4: HT29 Cells Growth kinetic of the control and the treated cells with IL-GF extract and Taxol at A: exponential phase and B: death phase.

The number of cell generation (X) was decreased from 3.93 generations in control to 2.96 generations in the IL-GF extract-treated cells and 2.01 generations in the Taxol-treated cells. This finding showed a significant difference when compared the number of cell generations between the control and different treatments.

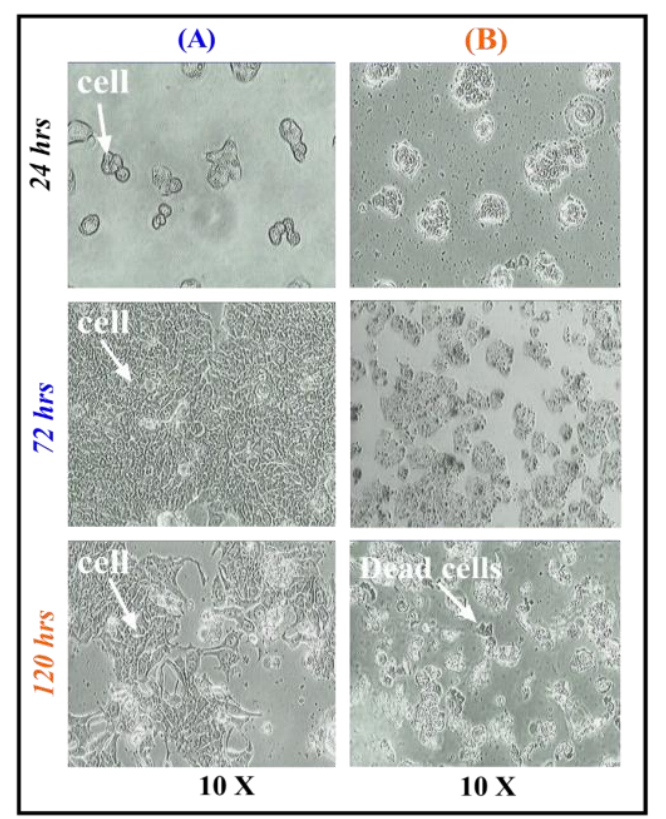

Fig. 5: The HT29 cells photographs of A: control cells and B: treated cells with IL-GF extract at a specified time point. 
The typical photographs of the control cells and the treated HT29 with IL-GF extract at 24, 72 and 120 hrs were shown in Fig. 5. The density of cells was reduced in the IL-GFE treated HT29 cells. That is probably because of the anti-proliferation effect of the IL-GF extract against HT29 cell growth.

The volume of cancer can be estimated in some types of tumours using the specific growth rate [38]. Thus, the IL-GF extract effect on the specific growth of HT29 cells was assessed by plotting the log number of cell viability versus treatment time, and the specific growth rate $(\mu)$ was taken from the regression slope. The growth rate of the treated HT29 cells with IL-GF extract and Taxol has significantly reduced by $0.0124 \mathrm{~h}^{-1}$ and $0.012 \mathrm{~h}^{-1}$, respectively compared to the control $0.0134 \mathrm{~h}^{-1}$.

\subsection{Cell Cycle Phase Distribution}

The distribution of cell cycle phases in the treated HT29 with IL-GF extract was analysed by flow cytometry combined with RNase A / Propidium iodide. The flow cytometry result showed that in the treated HT29 cells with IL-GF extract for 24, 48 and 72 hrs, the percentage of cells that were arrested at the G0/G1 phase has increased to $76.08 \%$ compared to the control $69.56 \%$ at $48 \mathrm{hrs}$ then reduced. In contrast, the percentage of cells has declined in phases S and G2M compared to the control cells (Fig. 6).

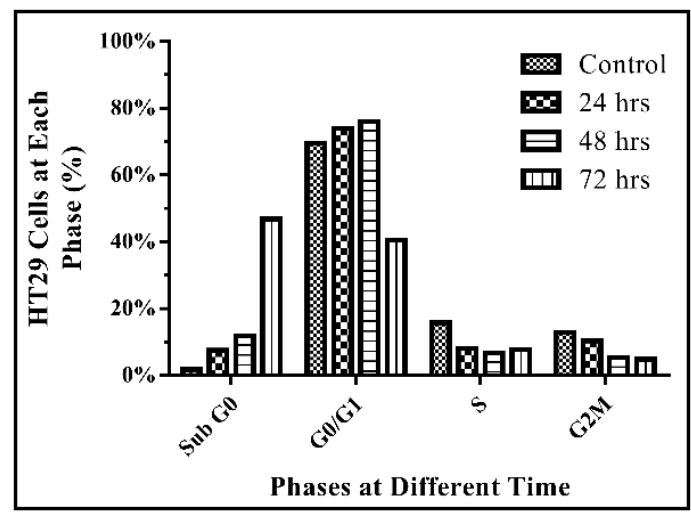

Fig. 6. Distribution of cell cycle phases of the treated HT29 cells with the corresponding $\mathrm{IC}_{50}$ of IL-GF extract in a time-dependent manner.

Furthermore, the treated HT29 cells showed an increase of cells arrested at the sub G0 phase in a time-increased treatment as compared with untreated HT29, considering the cells at the phase of sub-G0 as apoptotic cells [36]; there was an apparent increase of the apoptotic cells particularly after $48 \mathrm{hrs}$ treatment.

\section{DISCUSSION}

Fruit and vegetables are related to a healthy life and reduce the risk of diseases. That is undoubtedly due to the different phytochemicals and secondary metabolites, including alkaloids, phenols, carotenoids, vitamins and flavonoids that are important in strengthening immunity [39]. Many anti-cancer agents are used in cancer treatment, such as Taxol, topotecan, cisplatin, etoposide and doxorubicin [35]. However, cancer patients suffer from the severe side effect of these drugs related to their capacity to damage healthy cells. Hence, new anti-cancer drugs with fewer health risks are highly recommended to be investigated. The National Cancer Institute (USA) reported that any plant extracts showing an $\mathrm{IC}_{50}$ value under $20 \mu \mathrm{g} / \mathrm{mL}$ after a duration of incubation of 48 to $72 \mathrm{hrs}$ are considered as a potent cytotoxic substance [40]. 
Different identified phytochemicals in this study have been found to possess various biological activities. It was reported a long time ago that the Annonaceae family contained a considerable number of phytochemicals that exhibit anti-cancer activities such as acetogenins, alkaloids, terpenoids and flavonoids [41]. The claimed anti-cancer activity of several identified compounds have been reported, such as $\alpha$-D-mannopyranose in cloves of Allium sativum were showed cytotoxicity against breast cancer cells [42], tri-ruthenium dodecacarbonyl also was reported to have a highly selective anti-angiogenic against ovarian carcinoma A2780 cell lines [43,44]. Silanol trimethyl, D-psicose pentakis, and butanedioic acid have been reported to contribute to drug delivery system, anti-proliferation, apoptosis and cell cycle arrest in different cancer cells lines [45-47]. Another study reported that dihydro-dihydroxy-methyl-pyranone (DDMP) from onions had inhibited the growth of colon adenocarcinoma (HCT116 and SW620) cells by inducing apoptotic cell death, modulation of tumour necrosis factor- $\alpha(\mathrm{TNF}-\alpha)$ and DNA binding activity [48].

Moreover, Kameue et al. [49] reported that gluconic acid could induce apoptosis by stimulating butyrate production in the large intestine in a p53-independent manner and inhibiting cancer cell proliferation. These findings confirm the value of traditional use of the plant for medicinal purposes as well as pharmaceutical development. The use of Graviola fruit in herbal medicine has been supported by the existence of these bioactive compounds with proven health benefits and hence an interest for further research on this plant.

The anti-proliferative effect of the IL-GF extract was evaluated on adherent colon adenocarcinoma HT29 cell line. The IL-GF extract showed an anti-proliferative effect toward cancer cells as presented by MTT assay. Many previous studies have reported the anti-cancer activity of Graviola fruit toward many cancer cells, including human lung carcinoma A-549, breast adenocarcinoma MCF-7 cells, hepatoma HepG2 cell, prostate cancer PC-3 cells, and pancreatic tumour PACA-2 cell lines with comparable outcomes to our research findings [14,15,50-52]. Furthermore, the typical photographs of HT29 cells after treatment with IL-GFE and the control at designated time points displayed cell density reduction after treatment. The increase of apoptotic cells can be indicated by the changes in the morphology and biochemical of the HT29 cells, including DNA fragmentation and chromatin condensation, cell shrinkage and membrane blebbing [53]. Moreover, a recent study conducted by Daddiouaissa et al. [54] reported that after treating colon cancer HT29 cell line with IL-GF extract, the pathway analysis of metabolomic profiles showed an alteration of different metabolic pathways such as aerobic glycolysis, amino acid metabolism, ketone bodies metabolism and urea cycle that contribute to cancer cells proliferation and energy metabolism.

The growth kinetics model was investigated to estimate the inhibitory and cytotoxicity effects of IL-GF extract on HT29 cell growth. A general model was developed for colon adenocarcinoma HT29 cells in response to the treatment of IL-GF extract. Generally, efficient therapies decrease the cells' proliferation rate (cytostatic effect) and increase the death rate of the cells (cytotoxic effect). Many chemotherapy drugs disrupt the mechanism of cell division and dysregulate the cell cycle either through interfering or destroying DNA synthesis [55]. This can be confirmed when the doubling time has expanded from $22.46 \mathrm{hrs}$ in control to $24.27 \mathrm{hrs}$ and $25.08 \mathrm{hrs}$ for IL-GF extract and Taxol-treated HT29, respectively. The cytostatic effects can be observed at the log phase (Fig. 4A), whereas cytotoxic effects were clearly demonstrated at the death phase (Fig. 4B).

Although a biopsy sample is usually used to define the growth and spread of cancer growth and prescribe an effective therapy for it, the kinetics model in terms of simple 
formulas may help predict the tumour size in a function of time. The first-order linear equation for the untreated colon adenocarcinoma HT29 cell growth was given as follows:

$$
\log _{10} N=\log _{10} N_{0}+0.0134 t
$$

After treating HT29 cell lines with IL-GF extract, the equation of the first order linear presented as follows:

$$
\log _{10} N=\log _{10} N_{0}+0.0124 t
$$

Moreover, after treating HT29 cell lines with Taxol, the formula can be stated as follows:

$$
\log _{10} N=\log _{10} N_{0}+0.012 t
$$

However, if we neglect the tumour growth characteristics, the treatment's effectiveness can be estimated [38]. Therefore, the final equation of the kinetic model in response to IL-GF extract treatment was given as follows:

$$
\log _{10} \mathrm{Nf}=\left(\log _{10} N_{0}+0.0134 t\right)-\left(\log _{10} N_{0}+0.0124 t\right)
$$

Furthermore, the final equation of the kinetic model in response to Taxol treatment was given as follows:

$$
\log _{10} \mathrm{Nf}=\left(\log _{10} N_{0}+0.0134 t\right)-\left(\log _{10} N_{0}+0.012 t\right)
$$

where, $\left(\log _{10} \mathrm{~N}_{\mathrm{f}}\right)$ means the ultimate size of cancer after treatment, $\left(\log _{10} N_{0}\right)$ means the primary size of a tumour and $(t)$ means the treatment duration $\left(t_{\text {final }}-t_{\text {initial }}\right)$.

With this model, it is possible to identify the presence and the size of the early-stage tumours (less than $1 \mathrm{cc}$ ). The interpolation and extrapolation of tumour volume can be predicted at any time points. Cancer is classified as a cell cycle dysregulation disease. Thus, an effective drug can block cancer cell division [56]. After treatment, the cell cycle distribution of the HT29 cells was investigated using the flow cytometry technique to see whether IL-GF extract induced cell growth inhibition by cell cycle arrest. This study showed that IL-GF extract arrested the cell cycle of the treated HT29 at the G1 phase of the growthstatic, explaining the anti-proliferative effect of IL-GF extract. This confirmed the result of Moghadamtousi and co-workers [57] when treated colon cancer HCT-116 with ethyl acetate extract of $A$. muricata leaves.

Moreover, in our previous study, the flow cytometry result showed that IL-GF extract had induced apoptosis in breast adenocarcinoma MCF-7 cell lines [15]. This was also validated by Moghadamtousi et al. [57], and Chamcheu et al. [58] after treating nonmelanoma skin cancer NMSC and colorectal cancer HCT-116 and HT-29 with A. muricata leaves extract. On the other hand, Torres et al. [59] reported the induction of necrosis in pancreatic cancer PC cells when treated with the Graviola extract. This study concluded that Graviola extracts inhibit cell metabolism through numerous signalling pathways, metastatic properties and arrests the cell cycle machinery in pancreatic cancer cells.

Many investigated studies of the phytochemicals contained in the leaves and fruits of Graviola have extracted and identified a large number of secondary metabolites with a potential therapeutic such as anti-proliferative, apoptotic and cytotoxic towards many human cancer cells $[57,60]$. The synergistic effect of different metabolites in the Graviola fruit extract such as acetogenins, flavonoids, terpenes, and alkaloids may be responsible for its anti-proliferative effect. Thus, more investigations are still needed to detect the responsible active compounds for the anti-proliferation and inhibition effects of the Graviola fruit. 


\section{CONCLUSION}

The GC-TOFMS analysis of Graviola fruit extracted using IL-MAE confirmed the existence of various chemical groups of compounds like acetogenins, terpenoids, alkaloids, fatty acids, sugars and lactones. IL-GF extract presents anti-proliferative activity toward colon adenocarcinoma HT29 cell lines by inducing cell death through morphological changes, apoptosis, and the arrest of the cell cycle at the G0/G1 phase. This cytotoxicity showed selectivity toward the proliferation of colon cancer cells, indicating selective antitumor properties in IL-GF extract against tumour cells. Moreover, IL-GF extract showed a great potentiality anticancerous when compared to the positive control, Taxol. IL-GF extract has inhibited the growth of HT29 cells by decreasing the number of cell generations and increasing duplication duration compared with untreated cells. These findings suggest that IL-GF extract can be established as a new supplementary agent for preventing and curing colon cancer. Additional research to explain the mechanism attached to the therapeutic effects and define the responsible bioactive compounds for the fruit extract's cytotoxicity.

\section{ACKNOWLEDGEMENTS}

The authors are grateful to the International Islamic University Malaysia for offering a research grant (P-RIGS18-065-0075) and laboratory facilities.

\section{REFERENCES}

[1] Patel MS, Patel JK. (2016) A review on a miracle fruits of Annona muricata. Journal of Pharmacognosy and Phytochemistry, 5(1): 137-148.

[2] Ioannis P, Anastasis S, Andreas Y. (2015) Graviola: A systematic review on its anti-cancer properties. Am. J. Cancer Prev, 3(6): 128-131. https://doi.org/10.12691/ajcp-3-6-5

[3] Yajid AI, Ab Rahman HS, Wong MPK, Zain WZW. (2018) Potential benefits of Annona muricata in combating cancer: A Review. The Malaysian Journal of Medical Sciences, 25(1): 5-15. https://dx.doi.org/10.21315\%2Fmjms2018.25.1.2

[4] Badrie N, Schauss AG. (2010) Soursop (Annona muricata L.): composition, nutritional value, medicinal uses, and toxicology. Bioactive Foods in Promoting Health, Elsevier, pp. 621-643. https://doi.org/10.1016/B978-0-12-374628-3.00039-6

[5] Coe FG. (2008) Rama midwifery in eastern Nicaragua. Journal of Ethnopharmacology, 117(1): 136-157. https://doi.org/10.1016/j.jep.2008.01.027

[6] Samuel AJSJ, Kalusalingam A, Chellappan DK, Gopinath R, Radhamani S, Husain HA, Muruganandham V, Promwichit P. (2010) Ethnomedical survey of plants used by the Orang Asli in Kampung Bawong, Perak, West Malaysia. Journal of Ethnobiology and Ethnomedicine, 6(1): 1-6. https://doi.org/10.1186/1746-4269-6-5

[7] Tisott G, Molin D, Colet C. (2013) The use of medicinal plants and herbal medicines for patients in chemotherapy in an oncology center of Iju1/RS. O Mundo da Saude, 39(3): 287298.

[8] George VC, Kumar D, Rajkumar V, Suresh P, Kumar RA. (2012) Quantitative assessment of the relative antineoplastic potential of the n-butanolic leaf extract of Annona muricata Linn. in normal and immortalised human cell lines. Asian Pacific Journal of Cancer Prevention, 13(2): 699-704. https://doi.org/10.7314/APJCP.2012.13.2.699

[9] Monigatti M, Bussmann RW, Weckerle CS. (2013) Medicinal plant use in two Andean communities located at different altitudes in the Bolívar Province, Peru. Journal of Ethnopharmacology, 145(2): 450-464. https://doi.org/10.1016/j.jep.2012.10.066

[10] Betancur-Galvis LA, Saez J, Granados H, Salazar A, Ossa J. (1999) Antitumor and antiviral activity of Colombian medicinal plant extracts. Memórias do Instituto Oswaldo Cruz, 94(4): 531-535. http://dx.doi.org/10.1590/S0074-02761999000400019 
[11] Dai Y, Hogan S, Schmelz EM, Ju YH, Canning C, Zhou K. (2011) Selective growth inhibition of human breast cancer cells by graviola fruit extract in vitro and in vivo involving downregulation of EGFR expression. Nutrition and Cancer, 63(5): 795-801. https://doi.org/10.1080/01635581.2011.563027

[12] Gavamukulya Y, Abou-Elella F, Wamunyokoli F, AEl-Shemy H. (2014) Phytochemical screening, anti-oxidant activity and in vitro anti-cancer potential of ethanolic and water leaves extracts of Annona muricata (Graviola). Asian Pacific Journal of Tropical Medicine, 7(13): S355-S363. https://doi.org/10.1016/S1995-7645(14)60258-3

[13] Daddiouaissa D, Amid A. (2018) Anti-cancer activity of acetogenins from Annona muricata fruit. International Medical Journal Malaysia, 17(3): 103-112. https://doi.org/10.31436/imjm.v17i3.236

[14] Sun S, Liu J, Sun X, Zhu W, Yang F, Felczak L, Dou QP, Zhou K. (2017) Novel Annonaceous acetogenins from Graviola (Annona muricata) fruits with strong anti-proliferative activity. Tetrahedron Letters, 58(19): 1895-1899. https://doi.org/10.1016/j.tetlet.2017.04.016

[15] Daddiouaissa D, Amid A, Kabbashi NA, Fuad FA, Elnour AM, Epandy MA. (2019) Antiproliferative activity of ionic liquid-Graviola fruit extract against human breast cancer (MCF7) cell lines using flow cytometry techniques. Journal of Ethnopharmacology, 236: 466-473. https://doi.org/10.1016/j.jep.2019.03.003

[16] Siegel RL, Miller KD, Jemal A. (2019) Cancer statistics, 2019. CA: A cancer journal for clinicians 69(1), 7-34. https://doi.org/10.3322/caac.21551

[17] Griffin A, Butow P, Coates A, Childs A, Ellis P, Dunn S, Tattersall M. (1996) On the receiving end V: patient perceptions of the side effects of cancer chemotherapy in 1993. Annals of Oncology, 7(2): 189-195. https://doi.org/10.1093/oxfordjournals.annonc.a010548

[18] Daddiouaissa D, Amid A, Syahida A, Elnour AM. (2020) Phytochemical analysis of ionic liquid-Graviola (Annona muricata) fruit extract and its acute toxicity on zebrafish early-life stages. Asia Pacific Journal of Molecular Biology and Biotechnology, 28(2): 113-124. https://doi.org/10.35118/apjmbb.2020.028.2.10

[19] Koel M, Kuhtinskaja M, Vaher M. (2020) Extraction of bioactive compounds from Catharanthus roseus and Vinca minor. Separation and Purification Technology, 252: 117438. https://doi.org/10.1016/j.seppur.2020.117438

[20] Ventura SPM, e Silva FA, Quental MV, Mondal D, Freire MG, Coutinho JAP. (2017) Ionicliquid-mediated extraction and separation processes for bioactive compounds: Past, present, and future trends. Chemical Reviews, 117(10): 6984-7052. https://doi.org/10.1021/acs.chemrev.6b00550

[21] Bogdanov MG. (2014) Ionic liquids as alternative solvents for extraction of natural products, alternative solvents for natural products extraction, Springer, pp 127-166.

[22] Cláudio AFM, Marques CF, Boal-Palheiros I, Freire MG, Coutinho JA. (2014) Development of back-extraction and recyclability routes for ionic-liquid-based aqueous two-phase systems. Green Chemistry, 16(1): 259-268. https://doi.org/10.1039/C3GC41999A

[23] Wang T, Wang Q, Li P, Yang H. (2019) Temperature-responsive ionic liquids to set up a method for the simultaneous extraction and in situ preconcentration of hydrophilic and lipophilic compounds from medicinal plant matrices. Green Chemistry, 21(15): 4133-4142. https://doi.org/10.1039/C9GC00995G

[24] Fan Y, Li W, Zhang S, Sun S, Yang L. (2020) Vitamin B3-based protic ionic liquids as green solvents for the isolation of astilbin from rhizoma smilacis glabrae. Industrial Crops and Products, 152: 112563. https://doi.org/10.1016/j.indcrop.2020.112563

[25] Hoenig M. (2001) Preparation steps in environmental trace element analysis - facts and traps. Talanta, 54(6): 1021-1038. https://doi.org/10.1016/S0039-9140(01)00329-0

[26] Gyamfi K, Sarfo D, Nyarko B, Akaho E, Serfor-Armah Y, Ampomah-Amoako E. (2011) Assessment of elemental content in the fruit of graviola plant, Annona muricata, from some selected communities in Ghana by instrumental neutron activation analysis. Elixir Food Sci, 41: 5671-5675. 
[27] Rahman NRHA, Idris A, Yunus NA, Mustaffa AA. (2019) Optimisation of ionic liquid-based microwave extraction of flavonoid and phenolic acid from Labisia pumila. AIP Conference Proceedings (Vol. 2124, No. 1, p. 020027), AIP Publishing LLC. https://doi.org/10.1063/1.5117087

[28] Bhan M, Satija S, Garg C, Dureja H, Garg M. (2017) A novel approach towards green extraction for glycyrrhitinic acid by ionic liquid based microwave assisted extraction and optimisation through response surface methodology. Pharmacognosy Journal, 9(6): 866-872. https://doi.org/10.5530/pj.2017.6.136

[29] Zhang Y, Liu Z, Li Y, Chi R. (2014) Optimisation of ionic liquid-based microwave-assisted extraction of isoflavones from Radix puerariae by response surface methodology. Separation and Purification Technology, 129: 71-79. https://doi.org/10.1016/j.seppur.2014.03.022

[30] Jang Z-H, Chung H-C, Ahn YG, Kwon Y-K, Kim J-S, Ryu J-H, Kim C-H, Hwang G-S. (2012) Metabolic profiling of an alcoholic fatty liver in zebrafish (Danio rerio). Molecular BioSystems, 8(7): 2001-2009. https://doi.org/10.1039/C2MB25073J

[31] Muhamad S, Jamilah B, Russly A, Faridah A. (2017) In vitro antibacterial activities and composition of Carica papaya cv. Sekaki/Hong Kong peel extracts. International Food Research Journal, 24(3): p976-984.

[32] Liu N, Yang HL, Wang P, Lu YC, Yang YJ, Wang L, Lee SC. (2016) Functional proteomic analysis revels that the ethanol extract of Annona muricata L. induces liver cancer cell apoptosis through endoplasmic reticulum stress pathway. Journal of Ethnopharmacology, 189: 210-217. https://doi.org/10.1016/j.jep.2016.05.045

[33] Chik WW, Amid A, Jamal P. (2010) Purification and cytotoxicity assay of tomato (Lycopersicon esculentum) leaves methanol extract as potential anti-cancer agent. Journal of Applied Sciences, 10(24): 3283-3288. https://dx.doi.org/10.3923/jas.2010.3283.3288

[34] Fouz N, Amid A, Hashim Y. (2013) Cytokinetic study of MCF-7 cells treated with commercial and recombinant bromelain. Asian Pacific Journal of Cancer Prevention, 14(11): 6709-6714. https://doi.org/10.7314/APJCP.2013.14.11.6709

[35] Magadi VP, Ravi V, Arpitha A. (2015) Evaluation of cytotoxicity of aqueous extract of Graviola leaves on squamous cell carcinoma cell-25 cell lines by 3-(4, 5-dimethylthiazol-2Yl)-2, 5-diphenyltetrazolium bromide assay and determination of percentage of cell inhibition at G2M phase of cell cycle by flow cytometry: An in vitro study. Contemporary Clinical Dentistry, 6(4): 529-533. https://dx.doi.org/10.4103\%2F0976-237X.169863

[36] Agu KC, Okolie NP, Falodun A, Engel-Lutz N. (2018) In vitro anti-cancer assessments of Annona muricata fractions and in vitro anti-oxidant profile of fractions and isolated acetogenin (15-acetyl guanacone). Journal of Cancer Research and Practice, 5(2): 53-66. https://doi.org/10.1016/j.jcrpr.2017.12.001

[37] Suhendar U. (2018) Geographical Effect on the Cytotoxic Activity of Annona muricata L. Leaves Extract Against MCF7 Cancer Cell. Fitofarmaka, 8(2): 12-19.

[38] Mehrara E, Forssell-Aronsson E, Ahlman H, Bernhardt P. (2007) Specific growth rate versus doubling time for quantitative characterisation of tumor growth rate. Cancer Research, 67(8): 3970-3975. https://doi.org/10.1158/0008-5472.CAN-06-3822

[39] Wang H, Oo Khor T, Shu L, Su Z-Y, Fuentes F, Lee J-H, Tony Kong A-N. (2012) Plants vs. cancer: a review on natural phytochemicals in preventing and treating cancers and their druggability. Anti-Cancer Agents in Medicinal Chemistry (Formerly Current Medicinal Chemistry-Anti-Cancer Agents), 12(10): 1281-1305. https://doi.org/10.2174/187152012803833026

[40] Boik J. (2001) Natural compounds in cancer therapy (Vol. 851). Oregon Medical Press, 1st ed.

[41] Coria-Tellez AV, Montalvo-Gónzalez E, Yahia EM, Obledo-Vázquez EN. (2018) Annona muricata: A comprehensive review on its traditional medicinal uses, phytochemicals, pharmacological activities, mechanisms of action and toxicity. Arabian Journal of Chemistry, 11(5): 662-691. https://doi.org/10.1016/j.arabjc.2016.01.004 
[42] Nazeer AA, Veeraiyan S, Vijaykumar SD. (2017) Anti-cancer potency and sustained release of phytosomal diallyl disulfide containing methanolic Allium sativum extract against breast cancer. International Research Journal of Pharmacy, 8(8): 34-40. https://doi.org/10.7897/2230-8407.088141

[43] Nazarov A, Nosova YN, Mikhalev O, Kovaleva O, Dyson P, Milaeva E. (2016) Antiproliferative activity of ruthenium and osmium clusters with phosphine ligands. Russian Chemical Bulletin, 65(2): 546-549. https://doi.org/10.1007/s11172-016-1335-x

[44] Nowak-Sliwinska P, Zava O, Van Beijnum JR, Groessl M, Chisholm DM, Ahmadi Z, McIndoe JS, Griffioen AW. (2013) Synthesis and characterisation of a new class of antiangiogenic agents based on ruthenium clusters. Scientific Reports, 3: 1485. https://doi.org/10.1038/srep01485

[45] Belayachi L, Aceves-Luquero C, Merghoub N, de Mattos SF, Amzazi S, Villalonga P, Bakri Y. (2017) Induction of cell cycle arrest and apoptosis by Ormenis eriolepis a Morrocan endemic plant in various human cancer cell lines. African Journal of Traditional, Complementary and Alternative Medicines, 14(2): 356-373. https://doi.org/10.21010/ajtcam.v14i2.37

[46] Cheng W, Liang C, Xu L, Liu G, Gao N, Tao W, Luo L, Zuo Y, Wang X, Zhang X. (2017) TPGS-functionalized polydopamine-modified mesoporous silica as drug nanocarriers for enhanced lung cancer chemotherapy against multidrug resistance. Small, 13(29): 1-12. https://doi.org/10.1002/smll.201700623

[47] Sui L, Dong Y, Watanabe Y, Yamaguchi F, Hatano N, Tsukamoto I, Izumori K, Tokuda M. (2005) The inhibitory effect and possible mechanisms of D-allose on cancer cell proliferation. International Journal of Oncology, 27(4): 907-912. https://doi.org/10.3892/ijo.27.4.907

[48] Ban JO, Hwang IG, Kim TM, Hwang BY, Lee US, Jeong H-S, Yoon YW, Kim DJ, Hong JT. (2007) Anti-proliferate and pro-apoptotic effects of 2, 3-dihydro-3, 5-dihydroxy-6-methyl4H-pyranone through inactivation of NF- $\mathrm{KB}$ in human colon cancer cells. Archives of Pharmacal Research, 30(11): 1455. https://doi.org/10.1007/BF02977371

[49] Kameue C, Tsukahara T, Ushida K. (2006) Alteration of gene expression in the colon of colorectal cancer model rat by dietary sodium gluconate. Bioscience, Biotechnology, and Biochemistry, 70(3): 606-614. https://doi.org/10.1271/bbb.70.606

[50] Consolacion Y, Geneveve S, Ming-Jaw D, Chien-Chang S. (2012) Acetogenins from Annona muricata. Pharmacognosy Journal, 4(32): 32-37. https://doi.org/10.5530/pj.2012.32.7

[51] Sun S, Liu J, Kadouh H, Sun X, Zhou K. (2014) Three new anti-proliferative Annonaceous acetogenins with mono-tetrahydrofuran ring from graviola fruit (Annona muricata). Bioorganic \& Medicinal Chemistry Letters, 24(12): 2773-2776. https://doi.org/10.1016/j.bmcl.2014.03.099

[52] Sun S, Liu J, Zhou N, Zhu W, Dou QP, Zhou K. (2016) Isolation of three new annonaceous acetogenins from Graviola fruit (Annona muricata) and their anti-proliferation on human prostate cancer cell PC-3. Bioorganic \& Medicinal Chemistry Letters, 26(17): 4382-4385. https://doi.org/10.1016/j.bmcl.2015.06.038

[53] Pieme CA, Kumar SG, Dongmo MS, Moukette BM, Boyoum FF, Ngogang JY, Saxena AK. (2014) Anti-proliferative activity and induction of apoptosis by Annona muricata (Annonaceae) extract on human cancer cells. BMC Complementary and Alternative Medicine, 14(1): 516. https://doi.org/10.1186/1472-6882-14-516

[54] Daddiouaissa D, Amid A, Sani MSA, Elnour AA. (2021) Evaluation of metabolomics behavior of human colon cancer HT29 cell lines treated with ionic liquid graviola fruit pulp $\begin{array}{lllll}\text { extract. Journal of } & \text { Ethnopharmacology, }\end{array}$ https://doi.org/10.1016/j.jep.2021.113813

[55] O'Reilly MS, Boehm T, Shing Y, Fukai N, Vasios G, Lane WS, Flynn E, Birkhead JR, Olsen BR, Folkman J. (1997) Endostatin: an endogenous inhibitor of angiogenesis and tumor growth. Cell, 88(2): 277-285. https://doi.org/10.1016/S0092-8674(00)81848-6 
[56] Mantena SK, Sharma SD, Katiyar SK. (2006) Berberine, a natural product, induces G1-phase cell cycle arrest and caspase-3-dependent apoptosis in human prostate carcinoma cells. Molecular Cancer Therapeutics, 5(2): 296-308. https://doi.org/10.1158/1535-7163.MCT-050448

[57] Moghadamtousi SZ, Karimian H, Rouhollahi E, Paydar M, Fadaeinasab M, Kadir HA. (2014) Annona muricata leaves induce G1 cell cycle arrest and apoptosis through mitochondriamediated pathway in human HCT-116 and HT-29 colon cancer cells. Journal of Ethnopharmacology, 156: 277-289. https://doi.org/10.1016/j.jep.2014.08.011

[58] Chamcheu J, Rady I, Chamcheu R-C, Siddique A, Bloch M, Banang Mbeumi S, Babatunde A, Uddin M, Noubissi F, Jurutka P. (2018) Graviola (Annona muricata) exerts antiproliferative, anti-clonogenic and pro-apoptotic effects in human non-melanoma skin cancer UW-BCC1 and A431 cells in vitro: Involvement of hedgehog signaling. International Journal of Molecular Sciences, 19(6): 1791. https://doi.org/10.3390/ijms19061791

[59] Torres MP, Rachagani S, Purohit V, Pandey P, Joshi S, Moore ED, Johansson SL, Singh PK, Ganti AK, Batra SK. (2012) Graviola: A novel promising natural-derived drug that inhibits tumorigenicity and metastasis of pancreatic cancer cells in vitro and in vivo through altering cell metabolism. Cancer Letters, 323(1): 29-40. https://doi.org/10.1016/j.canlet.2012.03.031

[60] Gajalakshmi S, Vijayalakshmi S, Devi Rajeswari V. (2012) Phytochemical and pharmacological properties of Annona muricata: A review. International Journal of Pharmacy and Pharmaceutical Sciences, 4(2): 3-6. 